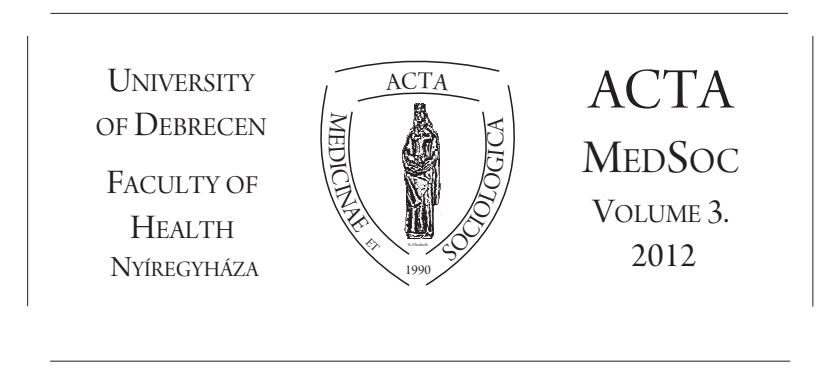

\title{
Presence of the Roma population on the settlements along the Hungarian-Romanian border
}

\author{
István Pásztor \\ Debreceni Egyetem, Társadalomföldrajzi és Területfejlesztési Tanszék \\ e-mail: susterfia83@freemail.hu
}

DOI: $10.19055 / \mathrm{ams} .2012 .3 / 6-7 / 5$

\section{General features of the border settlements}

The introductory thoughts of the present paper intend to summarise the general problems formerly outlined in relation to the area. Complex economic and social problems may be encountered also on the Hungarian side of the HungarianRomanian border region. One of its sources is that "In Hungary, among the changed circumstances following the First World War, the settlements located in the inner part of the country became border settlements, in many cases the centres of the regions were annexed by other countries, while the settlements belonging to their gravitation zones remained in Hungary." (SÜLI-ZAKAR, I. 2002)

The consequence of the modifications of historical borders, the fragmentation of the spatial structure that determined almost all elements of the economic and social systems of relations, and the double peripheral situation along the border were all the developments of the joint "mode of action" of the border location and the multiple disadvantaged situation strengthening each other. (BARANYI, B. 2006)

The territorial disparities inside the country are linked with severe social disadvantages, therefore, an attempt is made to correct them. One of the ways to do it is the self-correction of the local society: it attempts to adapt to the changing economic conditions, it endeavours to replace its unviable activities by new ones, or 
to adjust to the modifications of the spatial order of the society through migration. (ENYEDI, GY. 1993)

Former analyses also confirm that in the microregions of the Southern Transdanubian and Northern Hungarian regions, the settlement-level and later territorial concentration - and at the same time segregation and social and cultural unfeasibility - of the Roma ethnic group is linked to poverty. As a result of specific demographic and migration processes when the Gypsy population gets into majority then the settlement concerned gradually undergoes a natural ethnic homogenisation. (SZOBOSZLAI, ZS. 2006)

The present research, in addition to the above, intends to refine the data concerning the number of the Gypsy population in the region. The motivation was that there is no available database that could provide verified exact data about the settlements concerned.

\section{Applied methods}

The survey covered the settlementslying 20 air kilometres from the border (the distance measured from the border is set by the ArcView Program, selecting those settlement which lie $20 \mathrm{kms}$ from the border.) which belong to 16 microregions. ${ }^{1}$ In the course of the applied research, information was obtained from the selfgovernment leaders of the settlements (notary, mayor), population registry offices, family services, and local and county level Roma Minority Government leaders. As for the data collection, the verification of the data was mostly conducted on phone but it also happened that information was provided during private conversations.

The data collected was deemed proper to compare with the values of the CIKOBI database ${ }^{2}$ which allows for drawing conclusions, showing evolution of trends concerning the changes in the ethnic composition of the settlements.

\section{Results of the CIKOBI estimates for the region}

Looking at the data series of the settlements, we may experience that the estimates say that there were 50 settlements at that time where there was no Roma population at all, and on other 38 settlements their number did not exceed 100 .

\footnotetext{
${ }^{1}$ Microregions of Békéscsaba, Békés, Berettyóújfalu, Csenger, Derecske-Létavértes, Fehérgyarmat, Gyula, Hajdúhadház, Makó, Mátészalka, Mezókovácsháza, Nyírbátor, Orosháza, Sarkad, Szeged and Szeghalom.

${ }^{2}$ The data apply to the mid-eighties, relying on the numbers asked by the Coordination Committees for Gypsy Affairs of the county councils (CIKOBI) from the settlement level councils. Since the data are the estimates provided by the experts working for the local councils, therefore, they are probably very reliable on the smaller settlements. The 1992 estimates are regarded as the most reliable data even today. The estimates were made by Gábor Kertesi and Gábor Kézdi based on the number of Gypsy children in the primary schools, the population number published by the CSO in 1992, and the data of the Gypsy survey in 1993. This was the reason why it was preferred to be used instead of the census data.
} 


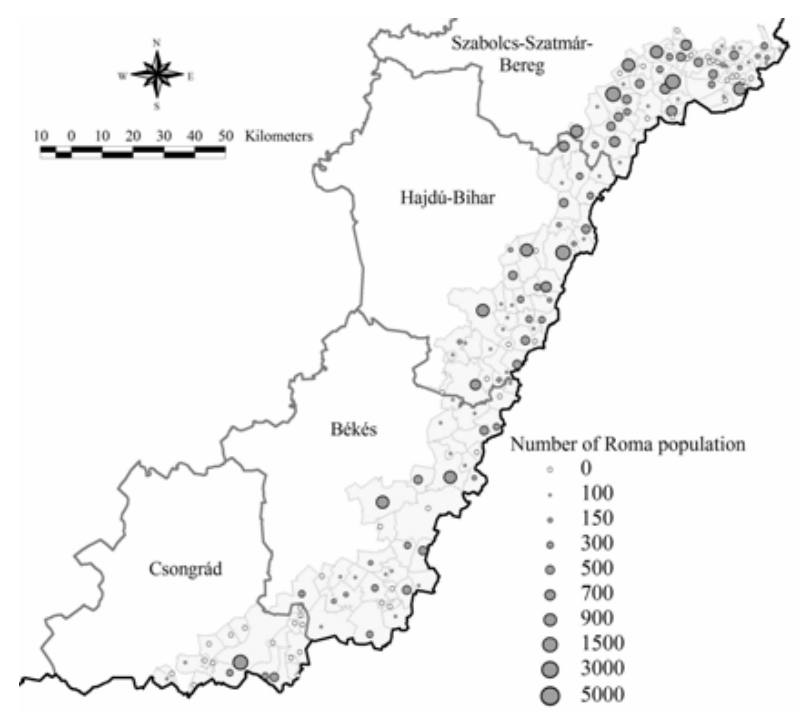

1. ábra. Figure 1. The number of the Roma population according to the CIKOBI estimates. Source: Based on Kertesi, G. - Kézdi, G. 1998 (ed.: Pénzes, J.)

The settlements with the highest Gypsy population at that time were Nyírbátor (1484), Makó (1495), Nagyecsed (1930) and Hodász (2517).

Nevertheless, if the ratios are also taken into consideration then the situation is somewhat different. Nagyecsed (22.6\%), Tisztaberek (26.9\%), Nyírpilis $(29.6 \%)$, Hodász $(38.3 \%)$ and Nyírmihálydi $(45.2 \%)$ boost the highest ratios.

As for those settlements where there is Roma population, on 64 of them their ratio does not reach $10 \%$.

On the basis of the above it may be safely established that at that time the number of Gypsies was not high on 114 of the 158 settlements $^{3}$. The maps illustrate it very clearly that as we move southward along the border, the data become more and more moderate, and only a few settlements (e.g.: Magyarcsanád 351 Gypsies, 19.7\%, Geszt 164 Gypsies, 15.2\%) represent outstandingly high values. Thus, based on the nearly twenty years old survey, it may be concluded that along the Hungarian-Romanian border it is the eastern part of Szabolcs-Szatmár-Bereg county where the process of "Romafication" can be observed already at that time.

\footnotetext{
${ }^{3}$ In this case the number of settlements fell to 158 because the CIKOBI did not provide estimate values for Méhtelek.
} 


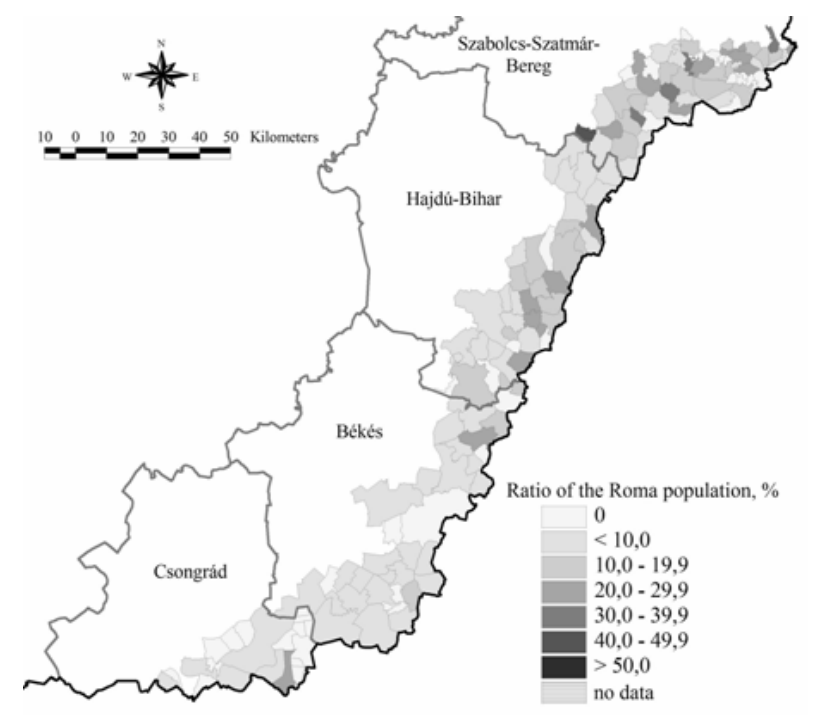

2. ábra. Figure 2 Ratio of the Roma population according to the CIKOBI estimates. Source: Based on Kertesi, G. - Kézdi, G. 1998 (ed.: Pénzes, J.)

\section{Results of the 2010-2011survey}

The primary aim of the survey is to determine the number of the Roma population both in absolute and relative terms applying the methods defined above, and to draw conclusions with regard to the future ethnic changes on the settlements.

Based on Figures 2 and 3 and Table 1, it may be established that significant ethnic changes have occurred in the past twenty years.

The most significant change occurring in the relations of the numbers of the Roma population (Figure 4) is that the number of settlements with no Gypsies at all lowered considerably. There are only 18 settlements in this category.

Besides, the number of Gypsies living on the settlements concerned has also increased considerably. There are 11 settlements where the number of the Roma population either reaches or exceeds 1 100. (Table 1) Settlements with significant Roma population also appear in the southern parts of the border zone. Good examples for that include Békéscsaba, Sarkad and Makó.

Nevertheless, even today, these are still the border regions of Szabolcs-SzatmárBereg county where the Gypsies are represented in the highest numbers (e.g. Nyírbátor, Mátészalka, Csenger and Nagyecsed).

As for the settlements of Hajdú-Bihar county, Hosszúpályi and Létavértes are the most highly affected but their values are not so outstanding. 


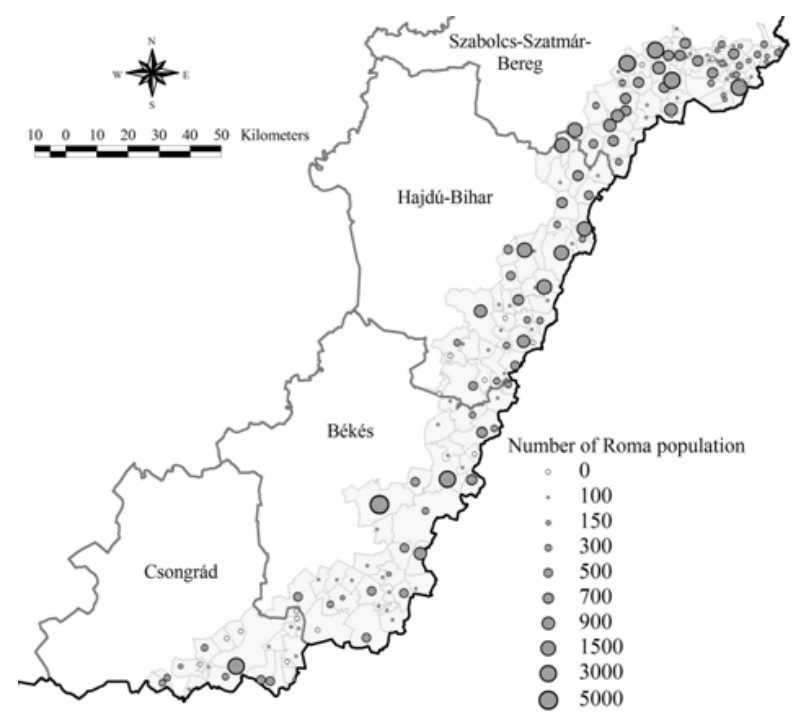

3. ábra. Figure 3 The number of the Roma population in 2010/2011. Source: Based on own data collection (ed.: Pénzes, J.)

\begin{tabular}{|l|c|l|c|}
\hline Settlement & Roma population & Settlement & Ratio of Roma people \\
\hline Nyírbátor & 5250 & Nyírpilis & 75,0 \\
\hline Békéscsaba & 3200 & Hodász & 61,3 \\
\hline Sarkad & 2300 & Mezógyán & 60,0 \\
\hline Hodász & 2107 & Told & 54,0 \\
\hline Mátészalka & 1900 & Szamostatárfalva & 53,8 \\
\hline Nagyecsed & 1900 & Nyírmihálydi & 53,4 \\
\hline Makó & 1660 & Bolt & 52,0 \\
\hline Csenger & 1500 & Komlódtótfalu & 50,0 \\
\hline Hosszúpályi & 1350 & Kötegyán & 48,0 \\
\hline Létavértes & 1300 & Rápolt & 45,8 \\
\hline
\end{tabular}

Table 1 Roma population on the settlements: the highest absolute numbers and the highest ratios.

There are 8 among the settlements along the border where the ratio of the Gypsies exceeds $50 \%$ on the settlement level.

Besides, as it may be seen on the map above, there are 15 settlements on the verge of ethnic realignment ${ }^{4}$. In the Sarkad microregion 3 of the settlements

\footnotetext{
${ }^{4}$ Those settlements were listed here where the proportion of the Roma population reaches at least $35 \%$.
} 


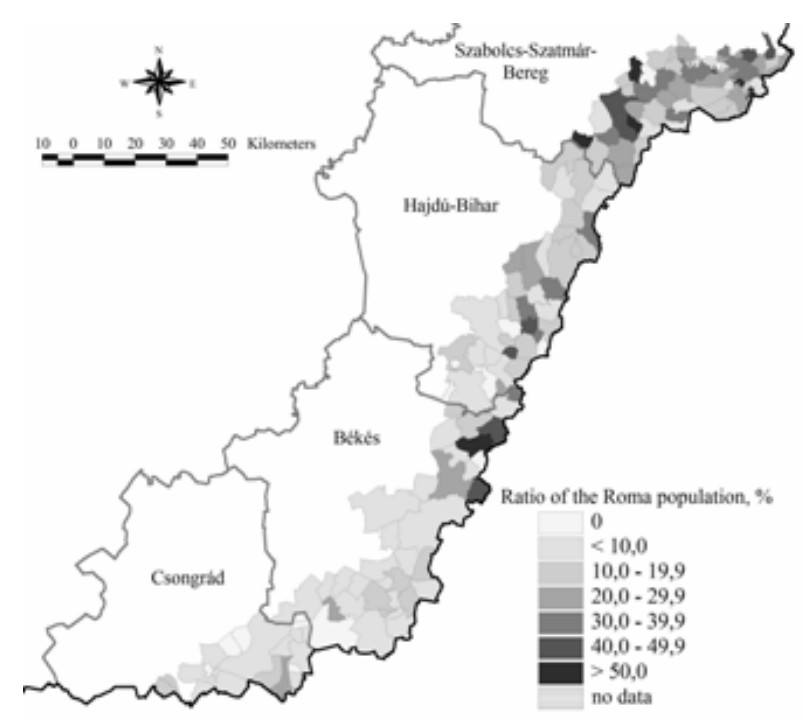

4. ábra. Figure 4 Ratio of the Roma population in 2010/2011. Source: Based on own data collection (ed.: Pénzes J.)

belong to this category (Kötegyán, Geszt and Körösnagyharsány), while from the Berettyóújfalu microregion Hencida and Bedő, and from the Derecske-Létavértes microregion Bagamér belong here. These data confirm that the highest Roma proportions occur more and more frequently in the southern areas of the border segment.

For the further differentiation of the area of the border zone, the settlements were also categorised on the microregional level ${ }^{5}$ primarily for finding out which microregions are the most highly affected by the ethnic composition changes.

On the basis of the above, it may be observed that the surveyed settlements of the Nyírbátor (Nyírmihálydi and Nyírpilis), Fehérgyarmat (Kisnamény and Tisztaberek), Csenger (Szamostatárfalva and Komlódtótfalu) and Mátészalka (Hodász and Rápolt) microregions consist of the biggest Roma communities with regard to their ratios. The relatively high aggregate data for the Sarkad microregion is partly determined by the outstanding value of Sarkad, and partly by the fact that there is one settlement among the 11 surveyed settlements where there is no Roma population at all.

\footnotetext{
${ }^{5}$ Only one settlements belongs to the Békés, Orosháza and Szeghalom microregions each, while there are 25 in the Berettyóújfalu microregion.
} 


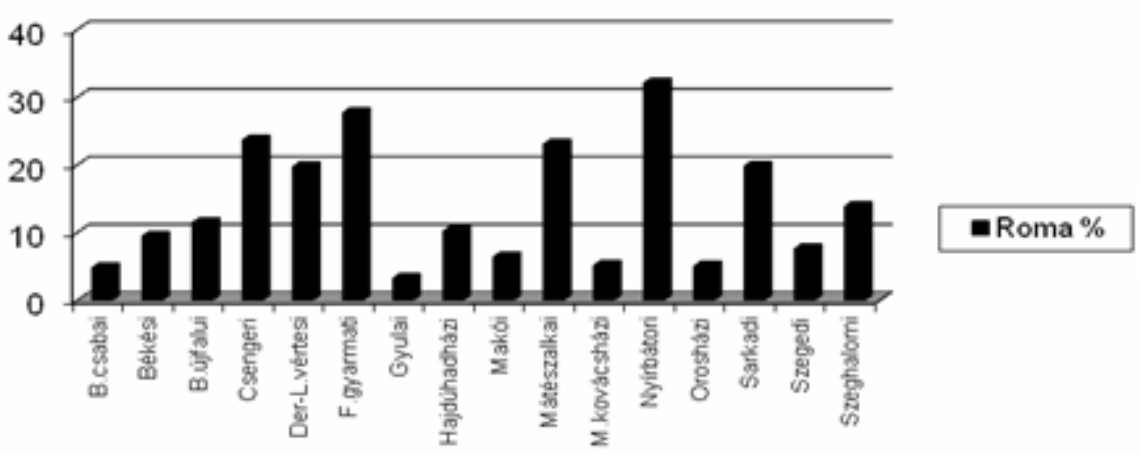

5. ábra. Figure 5 Ratios of the Roma population on the studied settlements of the microregions (2010/2011). Source: Based on own data collection.

\section{Comparison of the data of the survey with the CIKOBI est- imates}

Figures 6-7 demonstrate the differences between the two surveys. It, of course, clearly ensues from the above that the higher values were found in 2010/2011. Nevertheless, if the data are studied more thoroughly then it will be seen that increase is proved in the case of 125 settlements, while the values are lower than the CIKOBI estimates in the case of 20 settlements and 13 has stagnating values - covering those settlements where neither of the surveys found Roma population.

The most intensive increase in the number of the Gypsies is found in Nyírbátor, Békéscsaba, Sarkad, Mátészalka, Nyírmihálydi and Csenger. These data - except for Nyírmihálydi - belong to microregion centres. The primary reason for the growth can be migration whose causes may be searched for in the better economic, infrastructural and social circumstances.

The negative changes are not as unambiguous to be explained. These may be observed mainly in Hodász, Ököritófülpös, Komádi, Monostorpályi, Berekböszörmény and Kismarja. The results of the 2010/2011 survey confirm that in Hodász and in Ököritófülpös the ratio of the Roma population increased despite of the decrease in their absolute number, while in the case of Komádi, Monostorpályi and Berekböszörmény the moderately negative tendency may be detected in the ratios as well. Kismarja is in a special situation since according to the CIKOBI estimates it had 141 Romas but today there is not one person belonging to the Roma ethnic group on this settlement.

Calculating the average from the changes in the number of the Roma population, a growth of 153 persons may be defined for each settlement. If, however, 


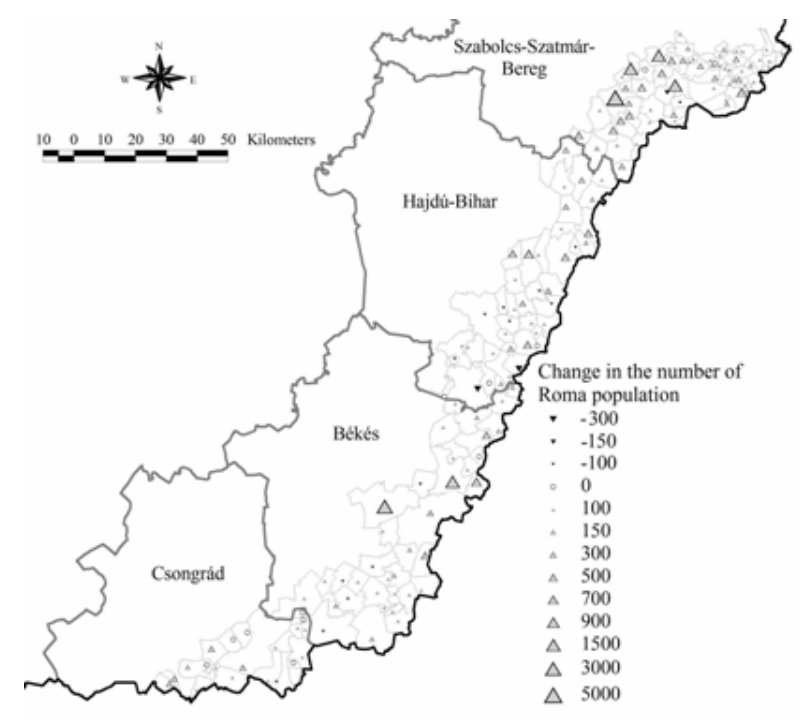

6. ábra. Figure 6 Changes in the number of Romas. Source: Kertesi, G. - Kézdi, G. 1998, own data collection (ed.: Pénzes J.)

those settlements are excluded from the list where there is no Roma population then the average growth is 167 persons per settlement.

If the changes are also analysed for the ratios then other kinds of differences may be also detected as compared to the changes in the absolute numbers. One of the chief causes for the significant differences is that the CIKOBI estimates did not assume to have Gypsies on those settlements where there were many of them living for a long time in a relatively high number.

These settlements include Told, Szamostatárfalva, Komlódtótfalu ${ }^{6}$ and Rápolt where today the ratio of the Roma population is around or exceeds $50 \%$ according to the $2010 / 2011$ survey.

The above mentioned settlements are followed by Nyírpilis, Kötegyán and Bojt where Roma population was already found at the time of the CIKOBI estimates but the rate of changes in the proportions also exceeds $30 \%$ in their cases.

According to the comparison, there are 13 settlements where the ratios decreased in the past twenty years. From among these, the most significant decrease in the ratios was detected in Kokad, Kismarja, Váncsod and Esztár - though none

\footnotetext{
${ }^{6}$ The great "Szamos flood" in 1970 almost entirely destroyed the village. After 1970 five settlements (Komlódtótfalu, and the villages of Nagygéc, Kishodos, Nagyhodos, and Garbolc disappeared since then) got stuck between the defence embankment and the state border where the state did not give aid for building new houses due to the flood risk. Therefore, the majority of the inhabitants of the settlements decided to leave the village, and it was followed by the settling of the Roma population and the drastic growth of their proportion.
} 


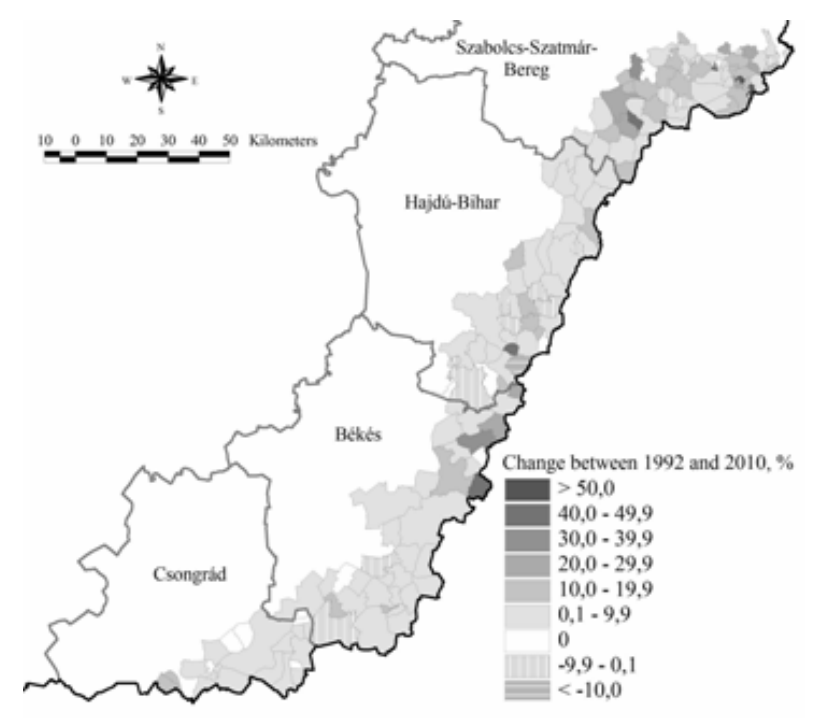

7. ábra. Figure 7 Changes in the number of the Roma population. Source: Kertesi, G. - Kézdi, G. 1998, own data collection (ed.: Pénzes J.)

of them exceeded $13 \%$. It is an interesting fact that the highest growth in ratios appeared in the case of some settlements in Szabolcs-Szatmár-Bereg and HajdúBihar counties while the decreases in the ratios may be mainly experienced only in Hajdú-Bihar county.

If an average is calculated for the ratios then a bit more than $10 \%$ increase is experienced for each settlement on average. In that case when those settlements are taken out where neither of the surveys found Roma population then this value is $10.76 \%$.

The comparison of the two surveys was also prepared for the level of microregions which showed that the number of the Roma population increased in every microregion except for one. Looking at Figure 8 it may be seen that this exception is the Békés microregion which, in terms of the present survey, consists of only one settlement (Doboz). On this settlement the ratio of the Gypsies decreased approximately by $0.2 \%$. In fact, we might as well say that their number remained the same.

The aggregated data regarding the settlements of the other fifteen microregions all show increase. The most significant growth is experienced on the settlements of the Békéscsaba, Nyírbátor and Sarkad microregions. Based on the above, it can be reasonably concluded that in the southern segment of the border the higher ratios of the Gypsies appeared in the past twenty years. 


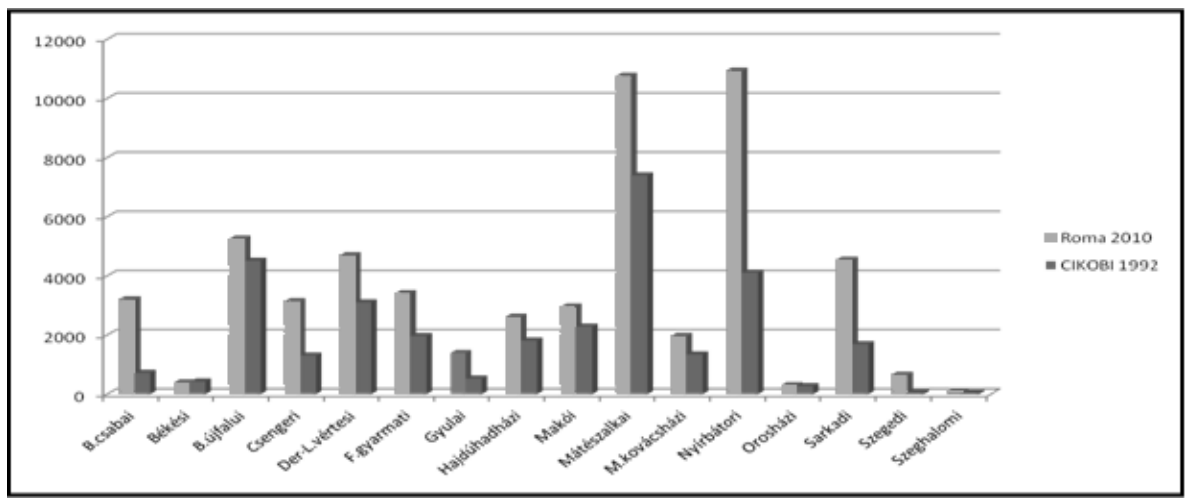

8. ábra. Figure 8 Differences between the two surveys by microregions. Source: Kertesi, G. - Kézdi, G. 1998, own data collection.

\section{Summary}

Conclusions may be drawn from the results of the two surveys regarding what had happened and what may be expected in the Hungarian-Romanian border region if the issue of the Roma population is raised. A significant ethnic realignment took place in the region over the past twenty years. The research confirmed that the number and proportion of the Gypsy population increased on the majority of the settlements. There are many settlements where the ratio of the Gypsies exceeds $50 \%$ and the ethnic ratios are expected to reverse on 10-15 settlements in the foreseeable future. The other phenomenon is that the process of "Romafication" appeared on the settlements in the border region farther south.

These changes should give a prod to take steps not to allow the presence of the Roma population exceeding the national average to be accompanied by deep poverty and social and cultural disadvantages. This phenomenon should be recognised in time and steps should be taken (by education and job creation) to ensure that this region avoids the total falling behind and definitively remaining "the periphery of periphery".

\section{References}

- BARANYI, B.: Gondolatok a perifériaképződés történeti elôzményeirôl és következményeiról. - Tér és társadalom 2004. évi 2. szám pp. 1-21.

- ENYEDI, GY.: Társadalmi-területi egyenlőtlenségek és területi politika Magyarországon. In.: Társadalmi-területi egyenlőtlenségek Magyarországon (szerk.: Enyedi György). Közgazdasági és Jogi Könyvkiadó, Bp., 1993. pp. 9-21. 
- KERTESI, G. - KÉZDI, G.: A cigány népesség Magyarországon (Dokumentáció és adattár). Socio-typo, Bp., 1998.

- SÜLI-ZAKAR, I.: A határok és a határmentiség szerepe a területfejlesztésben. Pál Ágnes (szerk.): Héthatáron. Tanulmányok a határ menti települések földrajzából. JGYF Kiadó, Szeged, 2002. pp. 71-92

- SZOBOSZLAI, ZS.: Szegénység, marginalizáció, szegregáció. Adalék a társadalmi egyenlótlenségek értelmezéséhez. Tér és társadalom. 2004. évi 3. szám pp. 25-42. 
Pásztor István Zoltán, doktorjelölt

Debreceni Egyetem, Társadalomföldrajzi és Területfejlesztési Tanszék 